\author{
Hanna Arola
}

\title{
Taimenen mädin säilyvyys ja alkioiden kasvu Savijoen kipsinlevitysalueella
}
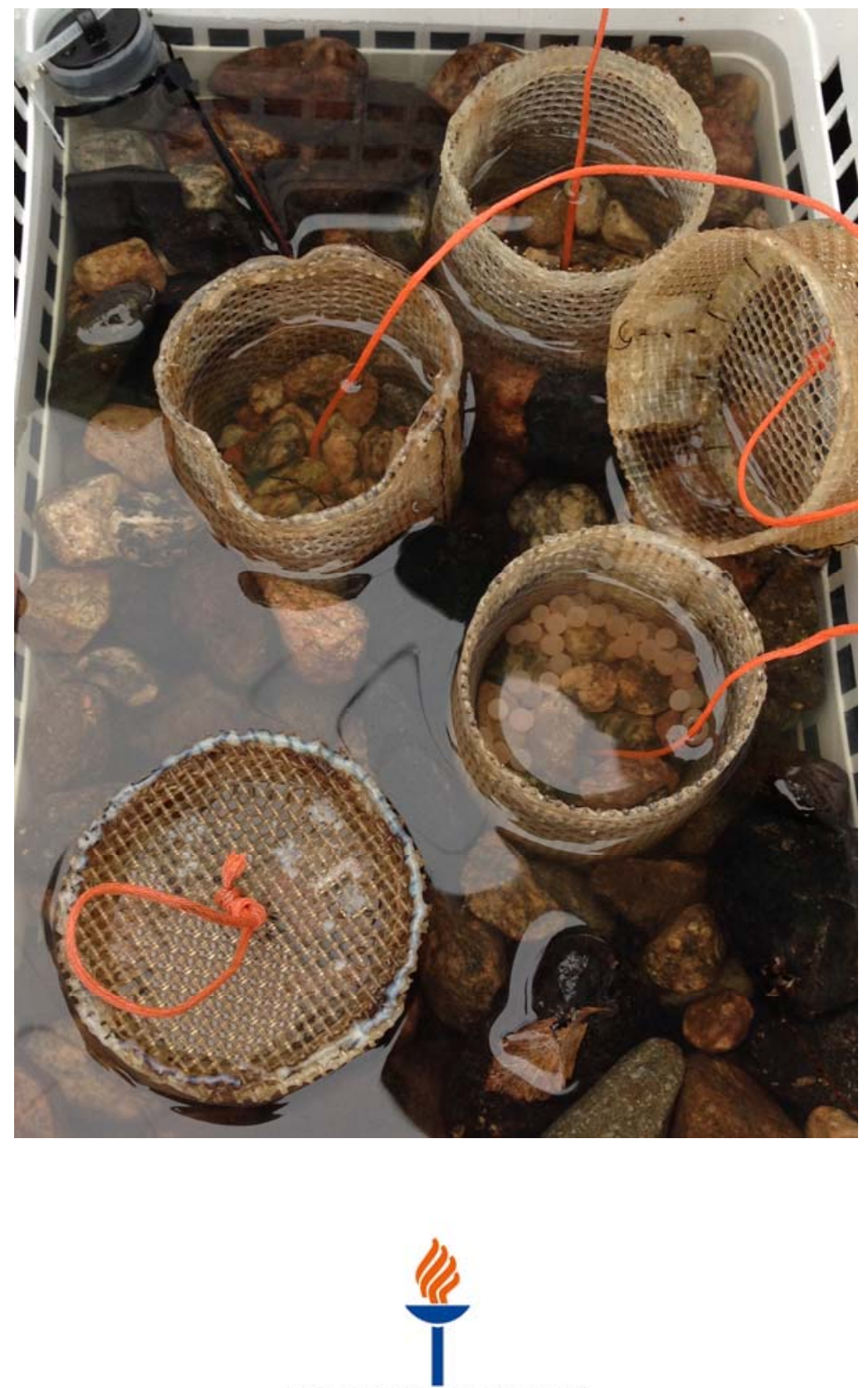
Jyväskylän yliopiston bio- ja ympäristötieteiden laitoksen tiedonantoja / Proceedings of the Department of Biological and Environmental Science, University of Jyväskylä

Toimittaja/Editor: Timo J. Marjomäki

Kansikuva/Cover photo: Maija Hannula

ISBN 978-951-39-7724-5 (PDF)

ISSN 2669-8986

Julkaisun pysyvä osoite / Permanent address to this publication:

http://urn.fi/URN:ISBN:978-951-39-7724-5

Jyväskylä 2019 


\section{TIIVISTELMÄ}

Arola, Hanna

Taimenen mädin säilyvyys ja alkioiden kasvu Savijoen kipsinlevitysalueella Jyväskylä: Jyväskylän yliopisto, 2019, 29 s.

Jyväskylän yliopiston bio- ja ympäristötieteiden laitoksen tiedonantoja 1/2019 ISSN 2669-8986

ISBN 978-951-39-7724-5 (PDF)

Pelloille tehtävän kipsinlevityksen vesistövaikutuksia tutkittiin Helsingin yliopiston ja Suomen ympäristökeskuksen yhteishankkeessa "SAVE - Saaristomeren vedenlaadun parantaminen peltojen kipsikäsittelyllä". Hanke oli ympäristöministeriön rahoittama hallituksen kärkihanke. Siinä missä kipsin, eli kalsiumsulfaatin, levitys on vähentänyt pelloilta tulevaa fosforikuormitusta, se on toisaalta nostanut pilottialuetta halkovan Savijoen sulfaattipitoisuuden kolminkertaiseksi. Suuren sulfaattipitoisuuden tiedetään olevan haitallista vesieliöille, kuten kaloille. Näin ollen Jyväskylän yliopisto selvitti kipsinlevityksen vaikutuksia taimenen (Salmo trutta) varhaisten elinvaiheiden säilyvyyteen ja kasvuun. Tutkimusmenetelmänä käytettiin mädinhaudontakoetta, joka alkoi lokakuussa 2017 ja päättyi toukokuussa 2018. Kokeessa oli kolme mädinhaudontapaikkaa: vertailu- ja kipsinlevitysalue Savijoella ja metsäisen valuma-alueen vertailupaikka läheisellä Järvijoella. Kipsikäsittelyn oletettiin joko lisäävän mädin säilyvyyttä vähentyneestä kiintoainekuormituksesta johtuen tai vähentävän sitä sulfaattipitoisuuden nousun seurauksena. Säilyvyys oli matala kaikilla koepaikoilla. Huhtikuussa keskimääräinen säilyvyys Savijoen vertailupaikalla, kipsinlevityspaikalla ja Järvijoella oli 7, 13 ja 26 \%. Toukokuuhun mennessä kaikki elävät alkiot olivat kuoriutuneet, mutta säilyvyys oli laskenut entisestään. Toukokuun lopulla Savijoella ei havaittu lainkaan eläviä yksilöitä, ja Järvijoella keskimääräinen säilyvyys oli 9 \%. Kaikkiin haudontasylintereihin oli kertynyt hiekkaa, mikä todennäköisesti vähensi säilyvyyttä. Alkioiden ja poikasten kasvu riippui pääsääntöisesti päiväastekertymästä, eikä yksilöiden pituudessa ollut suuria eroja eri paikkojen välillä. Kipsinlevityksen vaikutuksia taimenen varhaisiin elinvaiheisiin ei pystytty arvioimaan kunnolla sylintereihin kertyneestä hiekasta johtuen. Koe olisikin syytä toistaa, sillä tällä haudontakoejaksolla oli jokseenkin poikkeukselliset sääolot.

Hakusanat: Järvijoki; meritaimen; mädinhaudontakoe; SAVE-hanke; sulfaatti. 


\section{ABSTRACT}

Arola, Hanna

Survival and growth of brown trout early life stages in the River Savijoki affected by gypsum-treated fields Jyväskylä: University of Jyväskylä, 2019, 29 s.

Proceedings of the Department of Biological and Environmental Science, University of Jyväskylä 1/2019.

ISSN 2669-8986

ISBN 978-951-39-7724-5 (PDF)

In 2016, University of Helsinki and Finnish Environment Institute started a project SAVE "Saving the Archipelago Sea by applying gypsum to agricultural fields" to investigate the effects of gypsum treatment of agricultural fields on aquatic environment. Project SAVE was among the key projects of the Finnish Government, and The Finnish Ministry of Environment funded the project. The gypsum, i.e. calcium sulphate, treatment has decreased the phosphorus loading from the fields, but also tripled the sulphate concentration of the River Savijoki that intersects the pilot area. High sulphate concentration is known to be detrimental to aquatic organisms, such as fish. Thus, University of Jyväskylä investigated the effects of gypsum treatment on early life stage survival and growth of brown trout (Salmo trutta) by an in situ incubation method. The incubation experiment was started in October 2017 and finished in May 2018. Incubations were done at three sites. Savijoki sites included a reference site upstream from the gypsum treatment area and a gypsum treatment affected site. A second reference site representing a woodland catchment was in the nearby River Järvijoki. The gypsum treatment was expected either to increase the egg survival due to decreased loading of suspended solids, or to decrease it due to the higher sulphate concentration of the stream water. Survival was low at all study sites. In April, the mean survival was 7,13 and $26 \%$ at the Savijoki reference, gypsum-affected and Järvijoki reference site, respectively. All living embryos were hatched by May, but the survival had further decreased. By the end of May, living individuals were not observed at either of the Savijoki sites, and at the Järvijoki site the mean survival was $9 \%$. Sand had accumulated in every incubation cylinder, which likely decreased the survival. The embryonic and larval growth depended mainly on the accumulated degree days, and no notable difference in the total length of the individuals was observed among the three sites. The effect of the gypsum treatment could not be assessed due to the accumulation of sand. It would be worthwhile to repeat the experiment, since the weather conditions were somewhat exceptional during this incubation period.

Keywords: brown trout; in situ fish egg incubation; Järvijoki; project SAVE; sulphate. 


\section{SISÄLTÖ}

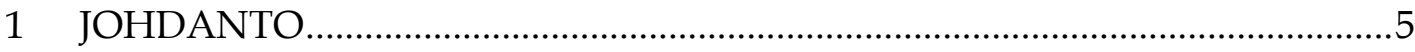

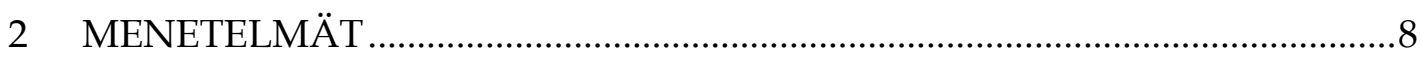

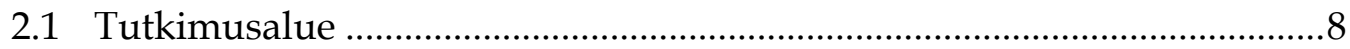

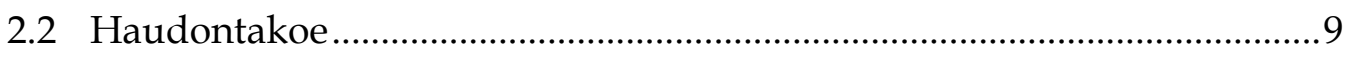

2.3 Vedenlaatu ja mikrohabitaatti ............................................................... 13

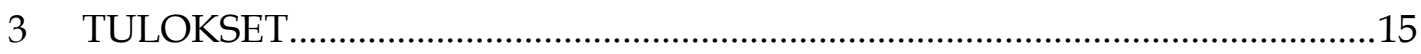

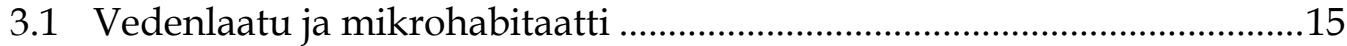

3.2 Säilyvyys, kuoriutuminen ja kasvu....................................................22

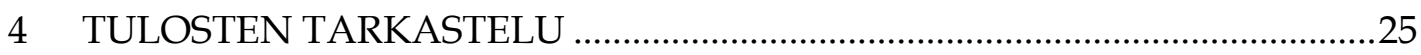

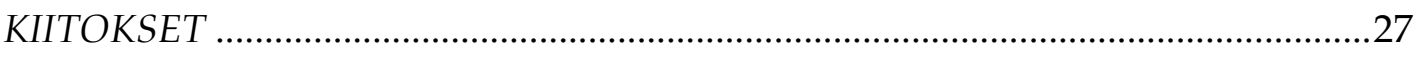

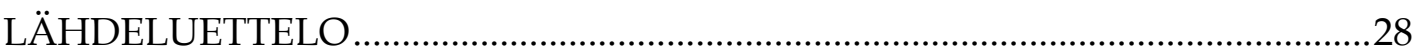




\section{JOHDANTO}

Vuonna 2016 alkaneessa Helsingin yliopiston ja Suomen ympäristökeskuksen SAVE-hankkeessa (Saaristomeren vedenlaadun parantaminen peltojen kipsikäsittelyllä) tutkittiin, voiko peltojen kipsikäsittely vähentää pelloilta tulevaa fosfori- ja kiintoainekuormitusta ja siten Saaristomeren rehevöitymistä (http://blogs.helsinki.fi/save-kipsihanke/). Hankkeen pilottialue koostui Liedon kunnan ja Paimion kaupungin alueilla sijaitsevista peltolohkoista, joista osaan levitettiin kipsiä, eli kalsiumsulfaattia $\left(\mathrm{CaSO}_{4} \cdot 2 \mathrm{H}_{2} \mathrm{O}\right)$, syksyllä 2016 (Kuva 1). Kipsinlevityksen vesistövaikutuksia on tutkittu muun muassa seuraamalla pilottialuetta halkovan Savijoen vedenlaatua. Tulosten perusteella kipsinlevitys on vähentänyt pelloilta tulevaa fosforikuormitusta selvästi, eritoten maaainekseen sitoutuneen fosforin osalta, verrattuna käsittelemättömiltä peltolohkoilta tulevaan kuormitukseen (SAVE-hanke, julkaisematon). Kipsinlevityksen vaikutuksen alaisella jokiosuudella kipsin sulfaatti on kuitenkin nostanut Savijoen veden keskimääräisen sulfaattipitoisuuden kolminkertaiseksi (noin 35 mg $\left.\mathrm{l}^{-1}\right)$ alueen tavanomaiseen pitoisuuteen (10-11 $\left.\mathrm{mg} \mathrm{l}^{-1}\right)$ verrattuna, ja hetkelliset sulfaattipitoisuushuiput ovat olleet jopa noin 30-kertaisia (maksimi $330 \mathrm{mg} \mathrm{l}^{-1}$ ) tavanomaiseen verrattuna (SAVE-hanke, julkaisematon).

Muissa tutkimuksissa sulfaatin on havaittu olevan haitallista muun muassa kalojen varhaisille elinvaiheille (Elphick ym. 2011, Wang ym. 2016). Kyseiset sulfaattipitoisuudet ovat pääsääntöisesti kuitenkin olleet korkeita verrattuina Savijoen sulfaattipitoisuuksiin; noin kuukauden kestäneissä jatkuvissa natriumsulfaattialtistuskokeissa Savijoen maksimipitoisuuksiin verrattavissa olevien sulfaattipitoisuuksien arvioitiin aiheuttavan noin $20 \%$ kuolleisuuden (paksupäämutu, Pimephales promelas, 34 vrk LC20 [95 \% luottamusväli]: $305 \mathrm{mg} \mathrm{l}^{-1}$ [277-336 mg l-1] ja $477 \mathrm{mg} \mathrm{l}^{-1}$ [456-499 $\left.\mathrm{mg} \mathrm{l}^{-1}\right]$, Wang ym. 2016) tai heikentävän alkioiden normaalia kehitystä ja kuoriutumista merkittävästi (kirjolohi, Oncorhynchus mykiss, 31 vrk LOEC: $340 \mathrm{mg} \mathrm{l}^{-1}$, Elphick ym. 2011). Sen sijaan varhaisten elinvaiheiden biomassa vaikutti olevan herkempi indikaattori, sillä sen arvioitiin olevan $20 \%$ pienempi kontrolliin verrattuna jo hieman matalammissa pitoisuuksissa (paksupäämutu 34 vrk EC20 [95\% luottamusväli]: $185 \mathrm{mg} \mathrm{l}^{-1}$ [106-323 $\left.\mathrm{mg} \mathrm{l}^{-1}\right]$ ja $106 \mathrm{mg} \mathrm{l}^{-1}$ [50-224 $\left.\mathrm{mg} \mathrm{l}^{-1}\right]$, Wang ym. 2016). 


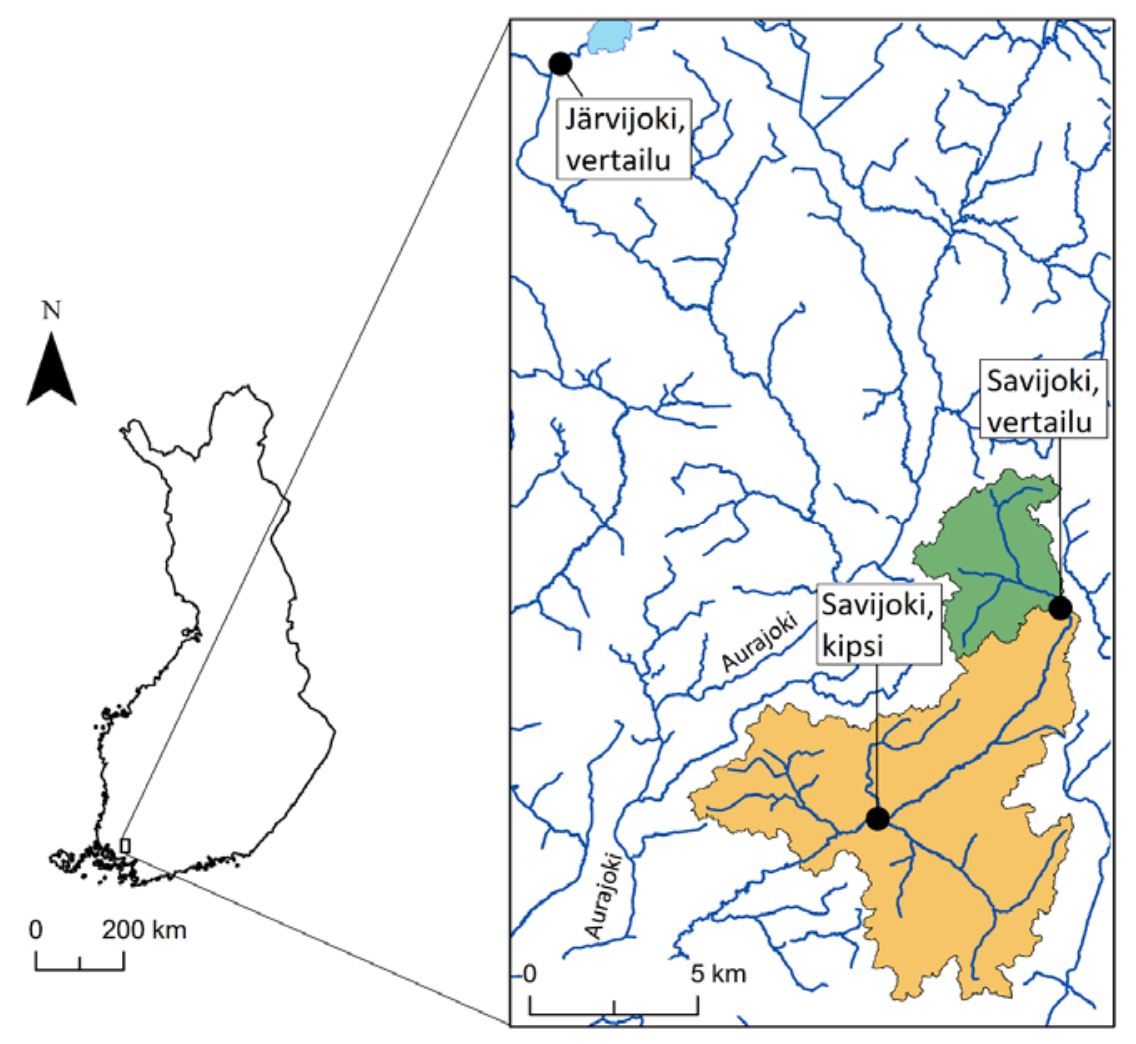

KUVA 1 Koealueen ja -paikkojen sijainti sekä Savijoen pilottialue. Savijoen valumaalueen kipsitön vertailualue on merkitty karttaan vihreällä ja kipsinlevitysalue keltaisella. Kipsinlevitysalueen koepaikka sijaitsi Koskelassa ja Savijoen vertailupaikka kipsittömän alueen alaosalla (noin $500 \mathrm{~m}$ kipsinlevitysalueen yläpuolella). Metsäisen valuma-alueen vertailupaikka Järvijoella sijaitsi noin 1,2 km alavirtaan Savojärvestä. Kartta-aineistot: Maanmittauslaitos 2018, avoimien aineistojen tiedostopalvelu (Suomen yleiskartta, ladattu 11/2016, ja maastokartta, ladattu 2/2018); Suomen ympäristökeskus 2018a, latauspalvelu LAPIO (Ranta10 - joet, ladattu 7/2018, Ranta10 - uomaverkostot, ladattu 7/2018); Suomen ympäristökeskus (Savijoen pilottialueiden valumaaluerajat). Kartat tehty: ArcGIS® v. 10.5.1 (ESRI Inc., Redlands, CA).

Sähkökoekalastusten perusteella Savijoen kalastoon kuuluvat muun muassa kivennuoliainen (Barbatula barbatula), kivisimppu (Cottus gobio), pikkunahkiainen (Lampetra planeri), törö (Gobio gobio), turpa (Squalius cephalus) ja taimen (Salmo trutta) (Koski ym. 2013, SAVE-hanke, julkaisematon). Savijoki kuuluu niihin Aurajoen sivujokiin, joissa taimenet vaikuttavat viihtyvän parhaiten, ja Savijoella on tehty taimenistutuksia (Koski ym. 2013). Myös taimenen luontainen lisääntyminen näyttää onnistuvan Savijoen sivupuroissa (Koski ym. 2013, SAVE-hanke, julkaisematon). Näin ollen Suomen ympäristökeskus päätti selvittää yhteistutkimushankkeena Jyväskylän yliopiston kanssa, vaikuttaako kipsinlevitys taimenen lisääntymismenestykseen Savijoella.

Tutkimusmenetelmäksi valittiin mädinhaudontakoe. Kokeessa vastahedelmöitettyä taimenen mätiä vietiin hautoutumaan koepaikoille lokakuun 2017 lopulla ja seuraavana keväänä määritettiin alkioiden säilyvyys, kasvu ja kuoriu- 
tuneiden osuus. Tämän pitkän, luonnossa tapahtuvan haudontajakson aikana saadaan altistusolosuhteiden osalta mahdollisimman todenmukainen käsitys siitä, voiko pelloille levitetty kipsi vaikuttaa taimenen luontaiseen lisääntymiseen.

Kokeessa mädin säilyvyyttä ja alkioiden kasvua seurattiin kipsinlevityksen vaikutuksen alaisella jokiosuudella, kipsikäsittelyn ulkopuolisella jokiosuudella ja metsäisen valuma-alueen joella (Kuva 1). Savijoella peltojen kipsikäsittely voi joko lisätä tai heikentää taimenen mädin säilyvyyttä ja alkioiden kasvua. Kipsikäsittelyn aiheuttama kiintoainekuormituksen väheneminen saattaa lisätä mädin säilyvyyttä ja parhaimmillaan kipsikäsittelyn vaikutuksen alaisella jokiosuudella mädin säilyvyys ja alkioiden kasvu saattaisikin olla metsäisen valuma-alueen joen tasolla. Huonoimmillaan kipsikäsittelyn aiheuttama veden sulfaattipitoisuuden nousu saattaa heikentää mädin säilyvyyttä. 


\section{MENETELMÄT}

\subsection{Tutkimusalue}

Koepaikkoja oli kolme. Savijoella kipsikäsittelyn vaikutuksen alainen koepaikka sijaitsi Koskelassa ja kipsitön vertailualue Liedonperällä (Kuva 1). Metsäistä valuma-aluetta edustava vertailupaikka sijaitsi läheisellä Järvijoella noin 1,2 km päässä yläpuolisesta Savojärvestä (Kuva 1). Kaikissa koepaikoissa veden virtausolot ja joen pohjan laatu vastasivat taimenen kutupesien mikroympäristöä, eli pohja koostui pääsääntöisesti sorasta ja virtausnopeus oli kymmeniä senttejä sekunnissa (ks. Witzel ja MacCrimmon 1983, Syrjänen ym. 2013).

Savijoki on noin $30 \mathrm{~km}$ pitkä Aurajoen sivujoki (Suomen ympäristökeskus 2018 b), joka saa alkunsa pienistä latvapuroista. Savijoen valuma-alueen pintaala on 130,5 km² ja se koostuu pääasiassa maa- ja metsätalousmaasta (Suomen ympäristökeskus 2018b). Koska Savijoen valuma-alueella ei ole järviä, joen vedenkorkeus vaihtelee nopeasti. Keskimääräinen valunta Savijoen yläosan mittapadolla on 10,4 $1 \mathrm{~s}^{-1} \mathrm{~km}^{-2}$, mutta kevään ja syksyn tulvahuippuina valunta voi olla suurempikin (Suomen ympäristökeskus 2018b). Savijoessa on kaksi nousuestettä, Kärpijoenkoski ja Liedonperä (Koski ym. 2013).

Metsäistä valuma-aluetta edustava vertailupaikka oli läheisen Järvijoen yläosalla (Kuva 1). Järvijoki on noin 26 km pitkä Aurajoen sivujoki, joka saa alkunsa Savojärvestä (Suomen ympäristökeskus 2018b). Yläosiltaan pääosin metsäinen ja soinen Järvijoen valuma-alue on pinta-alaltaan noin $110 \mathrm{~km}^{2}$ (Suomen ympäristökeskus 2018b). Vuoden 2013 tietojen mukaan Savojärven pinnankorkeutta on säännöstelty Järvijoen luusuassa olevalla padolla ja säännöstelyn seurauksena virtaamavaihtelut Järvijoessa ovat olleet huomattavia (Koski ym. 2013). Järvijoessa on useita koskialueita ja kaksi nousuestettä: Prunkkalankoski ja alin koskialue, jonka nousueste on osittainen (Koski ym. 2013). Järvijokeen on istutettu taimenen poikasia, mutta ainakaan vuoden 2013 tietojen mukaan sähkökoekalastuksissa ei ollut havaittu taimenia, joten istutuksien arvioitiin olleen tuloksettomia (Koski ym. 2013). Tämän on arveltu liittyvän Savojärven säännöstelyyn ja siitä johtuvaan ajoittaiseen uoman kuivumiseen (Koski ym. 2013). 


\subsection{Haudontakoe}

Haudontakoe tehtiin Luonnonvarakeskuksen Isojoen meritaimenen viljelykannan mädillä. Mäti lypsettiin ja hedelmöitettiin Luonnonvarakeskuksen Laukaan kalanviljelylaitoksella 25.10.2017 ja desinfioitiin (Buffodine) 26.10.2017. Desinfioinnin jälkeen mäti pakattiin 50 munan erissä vedellä täytettyihin $5 \mathrm{dl}$ pulloihin ja vietiin haudontajokiin 26.10.2017. Kalanviljelylaitoksella mäti hedelmöitettiin $6,5^{\circ} \mathrm{C}$ :ssa vedessä ja seuraavan vuorokauden mäti pidettiin $7^{\circ} \mathrm{C}$ :ssa vedessä. Kuljetuslämpötila kylmälaukuissa oli noin $4,4^{\circ} \mathrm{C}$.

Koepaikoilla mätimunat siirrettiin pulloista muoviverkosta rakennettuihin haudontasylintereihin, joiden tilavuus oli noin $2 \mathrm{dl}$, halkaisija $63 \mathrm{~mm}$, korkeus $87 \mathrm{~mm}$ ja solmuväli $2 \mathrm{~mm}$. Sylinterin pohjalla oli noin $4 \mathrm{~cm}$ sorakerros, jonka päälle laitettiin yhden pullon mätimunat (50 munaa), jotka peitettiin noin $2 \mathrm{~cm}$ sorakerroksella. Tämän jälkeen sylinterin kansi laitettiin paikoilleen ja kiinnitettiin pohjaosaan muovinarulla. Sylinterit asetettiin joen pohjaan aukollisessa muovikorissa (pituus: $310 \mathrm{~mm}$, leveys: $220 \mathrm{~mm}$, korkeus: $140 \mathrm{~mm}$ ). Kuhunkin koriin laitettiin neljä haudontasylinteriä siten, että sylinterit olivat lomittain, jotta vesi pääsi virtaamaan esteettä jokaisen sylinterin läpi (Kuva 2a). Koreissa olevat sylinterit ympäröitiin soralla (Kuva $2 b$ ) ja korit asetettiin joen pohjaan poikittain veden virtaussuuntaan nähden. Jokaisessa koepaikassa oli kaikkiaan kolme koria, joissa kussakin neljä sylinteriä eli yhteensä 12 sylinteriä (600 mätimunaa). Kaikilla paikoilla korit olivat jotakuinkin peräkkäin ja noin $0,8-7 \mathrm{~m}$ päässä toisistaan (Kuva 3a-c). 


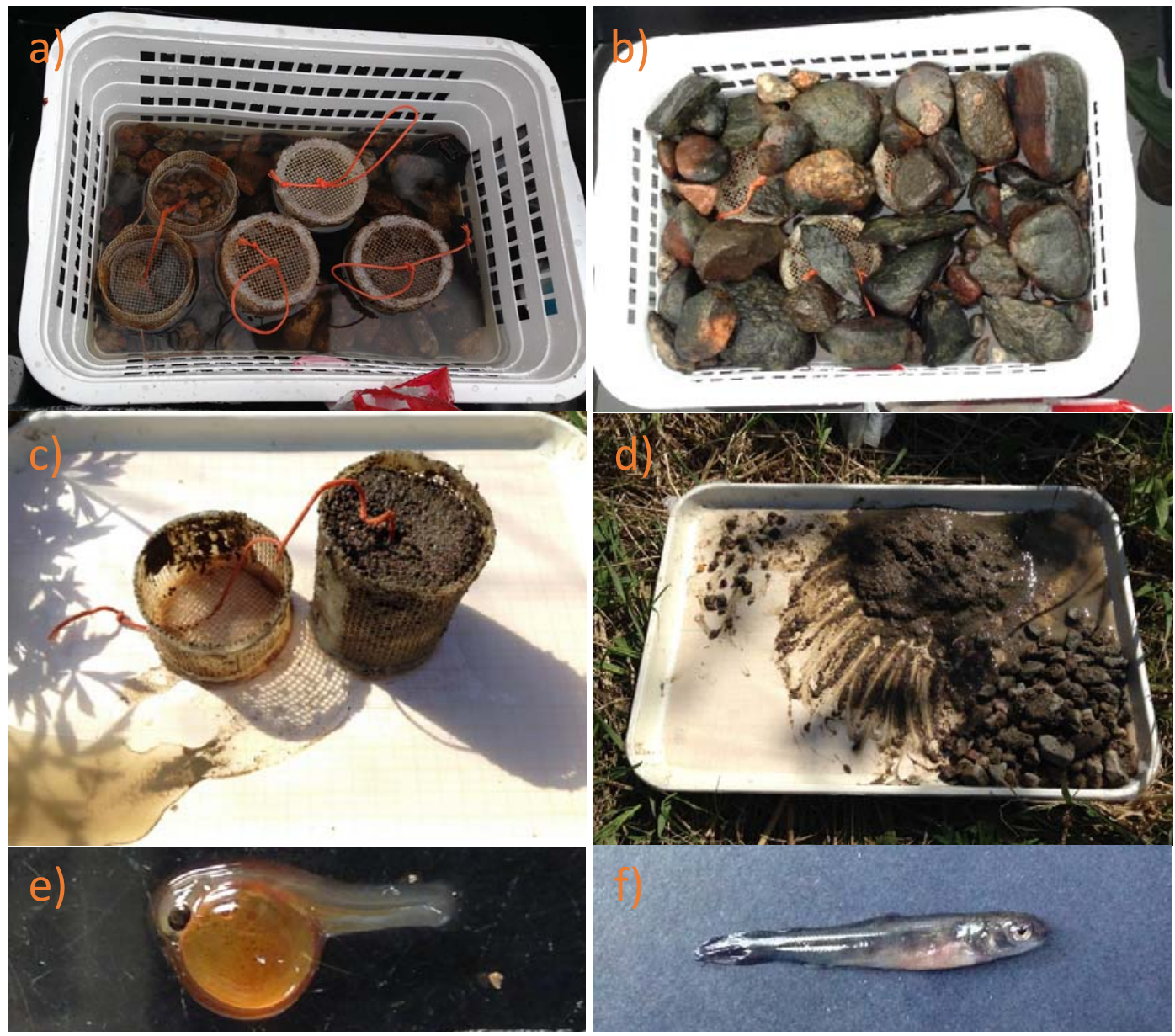

KUVA 2 Sylinterit korissa a) ennen niiden ympäröintiä soralla ja b) ympäröitynä soralla, ja kori valmis laitettavaksi jokeen. c) ja d) Keväällä näytteenottojen yhteydessä arvioitiin sylintereihin kertyneen hiekan määrä. e) Pituusmittausta varten munasta poistettu alkio 19.4.2018 näytteenotosta ja f) kuoriutunut poikanen 21.5.2018 näytteenotosta. (Kuvat: Maija Hannula). 

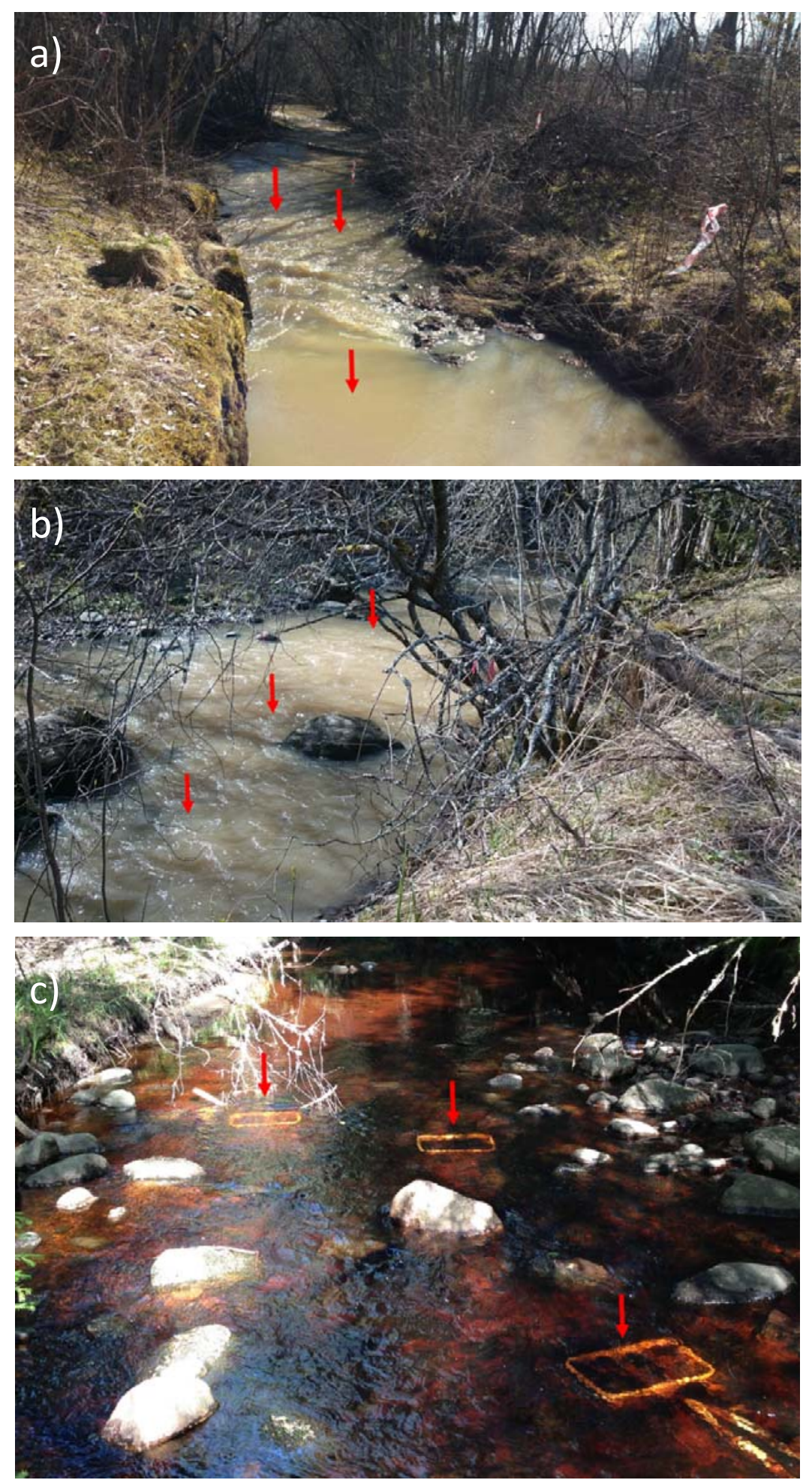

KUVA 3 Korien paikat Savijoen a) vertailu- ja b) kipsialueella sekä c) Järvijoella. Savijoen kuvat ovat alavirtaan ja Järvijoen kuva ylävirtaan katsottuna (Kuvat a ja c: Maija Hannula; b: Hanna Arola). 
Kokeen alussa sylintereihin laitettu sora oli suurimmalta halkaisijaltaan pääsääntöisesi 16-32 mm (68 \%) ja 8-16 mm (30 \%). Korisora koostui tuodusta (vallitsevan raekoon suurin halkaisija $32-64 \mathrm{~mm}$ ) ja joen pohjasta otetusta sorasta (raekoon suurin halkaisija 64-128 mm). Joen pohjalta siirrettiin kiviä ja soraa tekemällä < $5 \mathrm{~cm}$ syvyinen kuoppa, johon kori laitettiin ja tuettiin soralla ja kivillä. Kokeen alussa raekoko korien ympärillä oli suurimmalta halkaisijaltaan pääsääntöisesti 128-256 mm.

Haudontakorien tilanne käytiin tarkistamassa 12.1.2018. Kaikki korit olivat paikoillaan, eikä niitä tarvinnut siirtää. Savijoen kipsialueella oli muodostunut pohjajäätä, jota oli myös haudontakorien päällä. Jäätä naputeltiin varovasti irti koreista, mutta aivan kaikkea ei saatu poistettua. Järvijoen vertailupaikalla koreihin ja niiden ympärille oli kertynyt hiekkaa, jota poistettiin varovasti, mutta täydellistä hiekanpoistoa ei kuitenkaan tehty. Savijoen vertailualueella koreihin ei ollut kertynyt hiekkaa eikä siellä havaittu pohjajäätä.

Keväällä 2018 tehtiin neljä näytteenottoa. Sylintereiden näytteenottojärjestys määräytyi siten, että näytteenoton aloituspaikan ensimmäisenä nostettava sylinteri oli arvottu ja muut kyseisen paikan sylinterit nostettiin sitä seuranneessa järjestyksessä (esimerkiksi jos arvonta osui ylävirran korin sylinteriin 2, keskellä ja alimpana olleista koreista nostettiin sylinterit 3 ja 4). Muilla koepaikoilla nostettiin vastaavista koreista aina seuraava sylinteri edelliseen koepaikkaan nähden (esimerkiksi 3, 4 ja 1 sekä 4, 1 ja 2). Seuraavilla näytteenottokerroilla nostettiin aina näitä seuraavat sylinterit. Ensimmäisellä näytteenottokerralla (25.3.2018) näytteet kerättiin vain Järvijoen haudontakoreista, sillä Savijoella paksu jää ja vesi jään päällä estivät työskentelyn. Kaikista Järvijoen kolmesta haudontakorista nostettiin yksi sylinteri. Kahdella seuraavalla näytteenottokerralla (19.4. ja 8.5.2018) kaikkien paikkojen haudontakoreista nostettiin yksi sylinteri. Viimeisellä näytteenottokerralla (21.5.2018) nostettiin Savijoen kunkin korin kaksi viimeistä sylinteriä, ja vastaavasti Järvijoella jäljelle jääneet viimeiset sylinterit. Tuolloin myös korit kerättiin pois ja koe lopetettiin.

Jokaisella näytteenottokerralla kaikista sylinteristä laskettiin elävät ja kuolleet mätimunat, alkiot ja kuoriutuneet poikaset sekä otettiin 1-5 satunnaisesti valittua elävää alkiota tai poikasta pituusmittauksiin. Sylinterikohtainen säilyvyys (\%) laskettiin kaikkien elävien yksilöiden osuutena sylinterin alkuperäisestä munamäärästä $(50 \mathrm{kpl})$. Myös kuoriutuneiden osuus laskettiin osuutena sylinterin alkuperäisestä munamäärästä. Sekä säilyvyydelle että kuoriutuneille on tuloksissa ilmoitettu kunkin näytteenottokerran paikkakohtainen puulattu keskiarvo ja eksakti 95 \% luotettavuusväli (ks. Sergeant 2018). Elävien, kuolleiden ja kuoriutuneiden yksilöiden lukumäärät laskettiin heti nostojen jälkeen maastossa ja samalla arvioitiin myös sylintereihin kertyneen hiekan ja orgaanisen aineksen määrä silmämääräisesti (Kuva 2c \& d). Viimeisen näytteenoton yhteydessä jokaiselta paikalta otettiin myös yhden sylinterin ja yhden korin sisältö tarkempaan raekokoanalyysiin. Tarkemmassa raekokoanalyysissä kuivatettu sora jaoteltiin silmämääräisesti millimetripaperilla suurimman halkaisijan perusteella kokoluokkiin 0-8 mm, 8-16 mm, 16-32 mm, 32-64 mm, 64-128 mm ja 128-256 mm, ja nämä jakeet punnittiin. Lisäksi millimetripaperilla luokiteltu 0-8 mm jae seulottiin $0,5,1,0$ ja 2,0 mm seuloilla ravistimessa (Retsch) ja punnit- 
tiin. Valittujen sylintereiden ja korien raekokojakauman oli arvioitu edustavan kyseisen paikan keskimääräistä raekokojakaumaa sylintereissä ja koreissa kokeen lopussa.

Alkioiden pituus mitattiin Jyväskylän yliopiston bio- ja ympäristötieteiden laitoksen laboratoriossa seuraavana päivänä näytteenotosta. Alkio otettiin ulos munasta neulalla ja pinseteillä, minkä jälkeen se mitattiin stereomikroskoopilla (tarkkuus 0,1 mm) (25.3.) tai kuvattiin (19.4.) (Kuva 2e). Kuoriutuneet poikaset lopetettiin Samarinilla ja kuvattiin heti maastossa (8.5. ja 21.5.) (Kuva 2f). Kuvattujen alkioiden ja poikasten pituus määritettiin valokuvista ImageJ-ohjelmalla (ImageJ 1.51w, Wayne Rasband, National Institutes of Health, USA) (tarkkuus $0,1 \mathrm{~mm})$.

\subsection{Vedenlaatu ja mikrohabitaatti}

Suomen ympäristökeskus seurasi Savijoella muun muassa veden sähkönjohtavuutta ja sameutta sekä veden pinnan korkeutta kerran tunnissa rekisteröivillä mittalaitteilla ja laajemmin veden kemiallista laatua muutamia kertoja kuukaudessa otetuilla vesinäytteillä. Vedenlaadun seurantapaikkoja oli kolme: Liedonperä, Yliskulma ja Parmaharju. Liedonperän seurantapaikka sijaitsi mittapadolla, noin 50 m kipsittömän vertailualueen haudontakoepaikan alapuolella. Yliskulman seurantapaikka sijaitsi noin $1 \mathrm{~km}$ Koskelan koepaikan yläpuolella ja Parmaharjun seurantapaikka noin $2 \mathrm{~km}$ sen alapuolella. Mittapadon seurantapaikan tiedot kuvaavat haudontakokeen Savijoen vertailualueen vedenlaatua ja vastaavasti Yliskulman ja Parmaharjun tiedot Savijoen kipsipaikan vedenlaatua. Jatkuvatoimisten mittalaitteiden antaman veden sähkönjohtavuuden (Cond) ja laboratoriossa vesinäytteistä määritetyn veden sulfaattipitoisuuden $\left(\mathrm{SO}_{4}\right)$ välisen yhteyden (Ei kipsiä: $\mathrm{SO}_{4}=3,79+0,40 \times$ Cond, $n=72, r^{2}=0,48$, RMSE $=3,0$, Kipsiä: $\mathrm{SO}_{4}=11,94+0,07 \times$ Cond $^{2}-0,63 \times$ Cond, $n=69, r^{2}=0,76$, RMSE $=15,0)$ perusteella voitiin arvioida Savijoen veden sulfaattipitoisuus tunneittain. Savijoen veden kiintoainepitoisuus (TSS) taas arvioitiin vastaavasti jatkuvatoimisten mittalaitteiden antaman sameuden (Turb) perusteella (TSS = $5,92+1,02 \times$ Turb, $n=126, r^{2}=0,91$, RMSE = 26,1). Näistä laskettiin näytteenottojaksokohtaiset tunnusluvut. Järvijoen vedenlaatua ei seurattu tutkimusjaksolla, mutta vedenlaatutietoja kerättiin vuosilta 2000-2018 Suomen ympäristökeskuksen Hertta-tietokannasta (Suomen ympäristökeskus 2018b).

Kaikilla maastokäynneillä mitattiin veden syvyys korin keskilinjan kohdalta noin $20 \mathrm{~cm}$ korin edestä, korin etu- ja takasivuilta ja noin $20 \mathrm{~cm}$ korin takaa. Lisäksi veden virtausnopeus mitattiin samoilta kohdilta $2 \mathrm{~cm}$ pohjan yläpuolelta ja syvyydeltä $0,6 \times$ kokonaissyvyys kaikilla muilla kerroilla paitsi kokeen aloituksessa. Virrannopeus mitattiin Höntzsch-virrannopeusmittarilla paitsi tammikuussa MiniAir2-virrannopeusmittarilla (Schiltknecht). Veden lämpötilaa seurattiin jatkuvatoimisilla lämpötilatallentimilla (HOBO® Pendant®Temp/Light, 8K, 1-800-loggers, OnSet, mittaustarkkuus $0,2{ }^{\circ} \mathrm{C}$ ), joita oli yksi jokaisella koepaikalla yhteen kolmesta haudontakorista sijoitettuna. Läm- 
pötilatallentimet mittasivat jokiveden lämpötilaa 6 h välein. Näistä mittauksista laskettiin kunkin koepaikan vuorokauden keskimääräiset vedenlämpötilat, joiden perusteella laskettiin päiväastekertymät kullekin näytteenottohetkelle. Negatiiviset lämpötilat korvattiin nollalla laskettaessa päiväasteita. 


\section{TULOKSET}

\subsection{Vedenlaatu ja mikrohabitaatti}

Haudontakokeen alusta huhtikuun näytteenottoon saakka vaihtelut Savijoen valuma-alueen valunnassa olivat huomattavia (Taulukko 1, Kuva 4a). Joulukuussa havaittiin koko haudontakoejakson suurin $\left(144 \mathrm{l} \mathrm{s}^{-1} \mathrm{~km}^{-2}\right)$ valunta ja helmi-maaliskuussa pienin $\left(0,1 \mathrm{l} \mathrm{s}^{-1} \mathrm{~km}^{-2}\right)$. Kevättulva oli suurimmillaan huhtikuussa (Kuva 4a). Suurin kiintoainepitoisuus havaittiin loka-huhtikuun välisellä jaksolla kaikilla kolmella seurantapaikalla (Taulukko 1). Koko haudontakokeen ajan jokiveden $\mathrm{pH}$ oli sekä mittapadolla että Yliskulmassa ja Parmaharjulla pääsääntöisesti neutraali tai lievästi emäksinen. Sulfaattipitoisuus mittapadolla vaihteli välillä 5,0-19,8 mg 1-1 ja keskimääräinen pitoisuus oli kaikilla jaksoilla alle $10 \mathrm{mg} \mathrm{l}^{-1}$ (Taulukko 1, Kuva 4b). Yliskulmassa ja Parmaharjulla sulfaattipitoisuus oli suurempi, ja pitoisuuden keskiarvo oli eri mittausjaksoilla 15,4-25,4 $\mathrm{mg} \mathrm{l}^{-1}$ (Taulukko 1). Helmi-maaliskuussa Yliskulmassa ja Parmaharjulla havaittiin haudontakoejakson suurimmat sulfaattipitoisuuden arvot: 72,3 ja 76,1 $\mathrm{mg} \mathrm{l}^{-1}$ (Kuva 4b). Savijoen happipitoisuutta ei seurattu, mutta keväällä 2013 veden happipitoisuus mittapadolla oli 12,0-12,7 $\mathrm{mg} \mathrm{l}^{-1}$. 
TAULUKKO 1 Valunta ja vedenlaatu (keskiarvo \pm SE, alla min-max) Savijoen mittapadolla, Yliskulmassa ja Parmaharjulla näytteenottojaksoittain. Veden pH:lle on ilmoitettu pelkkä keskiarvo ja vaihteluväli.

\begin{tabular}{|c|c|c|c|c|c|c|c|}
\hline $\begin{array}{l}\text { Mittaus- } \\
\text { jakso ja } \\
\text {-paikka }\end{array}$ & $\begin{array}{l}\text { Valunta } \\
1 \mathrm{~s}^{-1} \mathrm{~km}^{2}\end{array}$ & $\begin{array}{l}\text { Kiinto- } \\
\text { aine } \\
\text { mg 1-1 }^{-1}\end{array}$ & $\begin{array}{l}\text { Sähkön- } \\
\text { johtavuus } \\
\text { mS m-1 }\end{array}$ & $\mathrm{pH}$ & $\begin{array}{l}\text { Alkalini- } \\
\text { teetti } \\
\text { mmol 1-1 }^{-1}\end{array}$ & $\begin{array}{l}\mathrm{SO}_{4} \\
\mathrm{mg} \mathrm{l-1}^{-1}\end{array}$ & $\begin{array}{l}\mathrm{Ca} \\
\mathrm{mg} \mathrm{l}^{-1}\end{array}$ \\
\hline \multicolumn{8}{|c|}{ 26.10.2017-19.4.2018 } \\
\hline Mittapato & $\begin{array}{l}16,5 \pm 0,3 \\
0,1-144,2\end{array}$ & $\begin{array}{l}96,0 \pm 1,4 \\
24,8-660,2\end{array}$ & $\begin{array}{l}14,4 \pm 0,1 \\
3,1-40,0\end{array}$ & $\begin{array}{l}7,1 \\
6,8-7,5\end{array}$ & $\begin{array}{l}1,14 \pm 0,37 \\
0,33-2,70\end{array}$ & $\begin{array}{l}9,6 \pm 0,1 \\
5,0-19,8\end{array}$ & $\begin{array}{l}10,2 \pm 0,1 \\
3,0-26,4\end{array}$ \\
\hline Yliskulma & & $\begin{array}{l}94,3 \pm 1,4 \\
21,2-519,0\end{array}$ & $\begin{array}{l}17,6 \pm 0,1 \\
4,7-34,6\end{array}$ & $\begin{array}{l}7,3 \\
7,1-7,7\end{array}$ & $\begin{array}{l}0,89 \pm 0,16 \\
0,37-1,60\end{array}$ & $\begin{array}{l}24,2 \pm 0,2 \\
10,5-72,3\end{array}$ & $\begin{array}{l}13,8 \pm 0,1 \\
4,2-32,2\end{array}$ \\
\hline $\begin{array}{l}\text { Parma- } \\
\text { harju }\end{array}$ & & $\begin{array}{l}85,5 \pm 1,2 \\
19,4-524,4\end{array}$ & $\begin{array}{l}18,2 \pm 0,1 \\
5,1-35,5\end{array}$ & $\begin{array}{l}7,3 \\
7,1-7,5\end{array}$ & $\begin{array}{l}0,93 \pm 0,18 \\
0,40-1,90\end{array}$ & $\begin{array}{l}25,4 \pm 0,2 \\
10,5-76,1\end{array}$ & $\begin{array}{l}14,4 \pm 0,1 \\
4,4-33,4\end{array}$ \\
\hline $20.4-8.5 .2018$ & & & & & & & \\
\hline Mittapato & $\begin{array}{l}17,3 \pm 0,6 \\
8,6-88,6\end{array}$ & $\begin{array}{l}75,8 \pm 2,5 \\
41,8-591,4\end{array}$ & $\begin{array}{l}9,2 \pm 0,0 \\
8,2-10,5\end{array}$ & 7,2 & 0,50 & $\begin{array}{l}7,5 \pm 0,0 \\
7,1-8,0\end{array}$ & $\begin{array}{l}6,9 \pm 0,0 \\
6,2-7,7\end{array}$ \\
\hline Yliskulma & & $\begin{array}{l}89,7 \pm 2,5 \\
52,5-395,7\end{array}$ & $\begin{array}{l}12,9 \pm 0,0 \\
11,4-14,9\end{array}$ & 7,3 & 0,56 & $\begin{array}{l}15,4 \pm 0,1 \\
13,7-17,8\end{array}$ & $\begin{array}{l}9,6 \pm 0,0 \\
8,5-11,2\end{array}$ \\
\hline $\begin{array}{l}\text { Parma- } \\
\text { harju }\end{array}$ & & $\begin{array}{l}88,7 \pm 2,6 \\
48,9-455,5\end{array}$ & $\begin{array}{l}14,4 \pm 0,0 \\
12,9-16,0\end{array}$ & 7,3 & 0,58 & $\begin{array}{l}17,2 \pm 0,1 \\
15,3-19,5\end{array}$ & $\begin{array}{l}10,8 \pm 0,0 \\
9,6-12,1\end{array}$ \\
\hline 9.-21.5.2018 & & & & & & & \\
\hline Mittapato & $\begin{array}{l}3,5 \pm 0,1 \\
0,9-8,8\end{array}$ & $\begin{array}{l}67,5 \pm 0,4 \\
1,5-88,2\end{array}$ & $\begin{array}{l}13,5 \pm 0,1 \\
10,5-17,9\end{array}$ & 7,5 & 0,80 & $\begin{array}{l}9,2 \pm 0,1 \\
8,0-11,0\end{array}$ & $\begin{array}{l}9,6 \pm 0,1 \\
7,7-12,4\end{array}$ \\
\hline Yliskulma & & $\begin{array}{l}66,2 \pm 0,7 \\
1,5-140,1\end{array}$ & $\begin{array}{l}17,4 \pm 0,1 \\
14,9-20,2\end{array}$ & 7,4 & 0,93 & $\begin{array}{l}21,9 \pm 0,2 \\
17,8-27,3\end{array}$ & $\begin{array}{l}13,3 \pm 0,1 \\
11,2-15,8\end{array}$ \\
\hline $\begin{array}{l}\text { Parma- } \\
\text { harju }\end{array}$ & & $\begin{array}{l}57,9 \pm 0,5 \\
41,8-84,7\end{array}$ & $\begin{array}{l}19,0 \pm 0,1 \\
15,9-22,5\end{array}$ & 6,9 & 0,76 & $\begin{array}{l}25,0 \pm 0,2 \\
19,3-32,5\end{array}$ & $\begin{array}{l}14,7 \pm 0,1 \\
12,0-18,1\end{array}$ \\
\hline
\end{tabular}



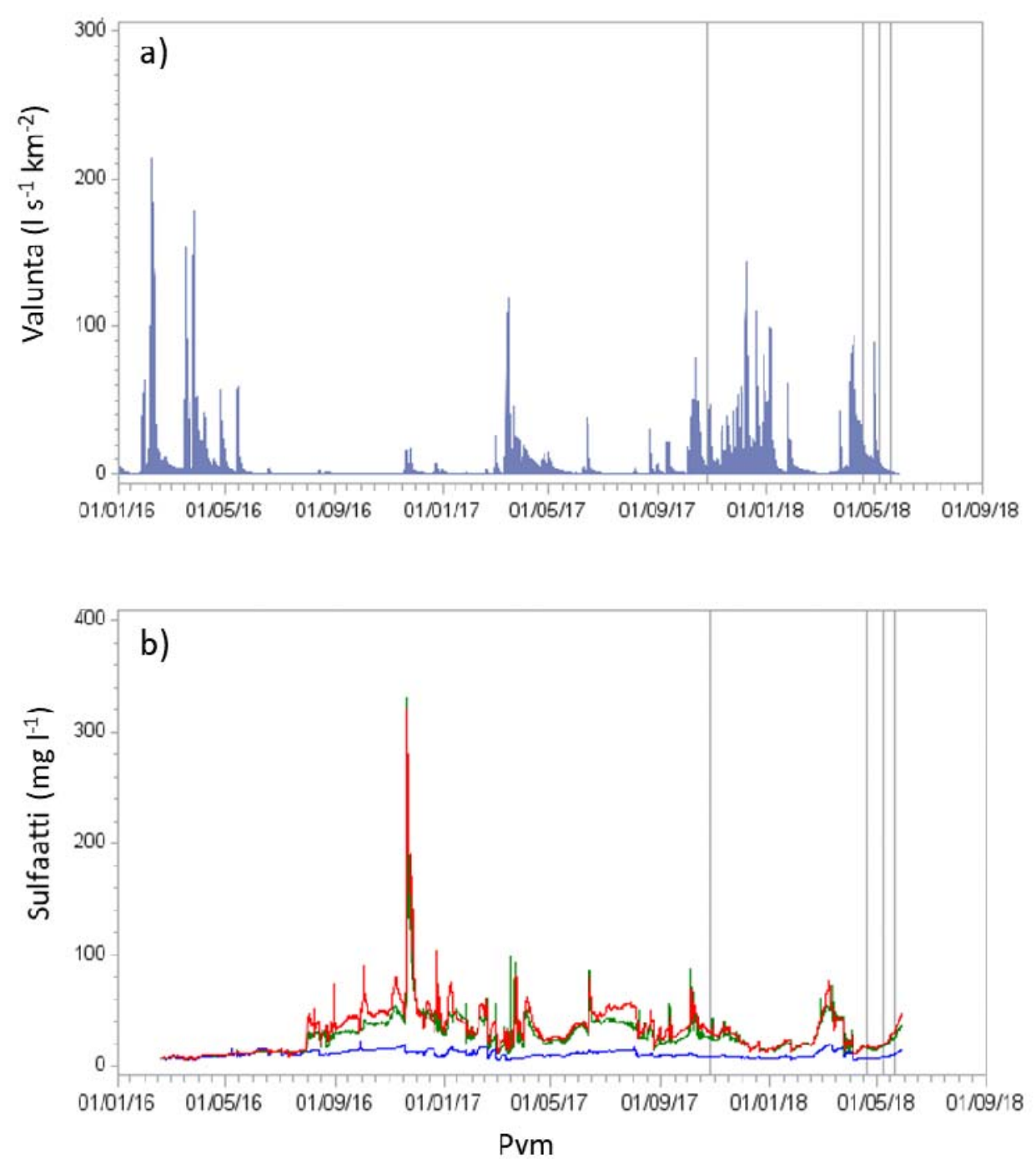

KUVA 4 Jakson 1.1.2016-30.5.2018 a) valunta Savijoen mittapadolla ja b) Savijoen sulfaattipitoisuus mittapadolla (sininen), Yliskulmassa (vihreä) ja Parmaharjulla (punainen). Ensimmäinen harmaa pystyviiva kuvaa haudontakokeen aloitusajankohtaa (26.10.20117) ja kolme seuraavaa viivaa huhti-toukokuun näytteenottoja (19.4., 8. ja 21.5.2018).

Vuosien 2000-2016 vedenlaatutulokset Järvijoen suulta ja yläpuolisesta Savojärvestä osoittavat, että veden $\mathrm{pH}$ vaihtelee happaman ja lievästi emäksisen välillä (Taulukko 2). Lisäksi Järvijoen suulla hapen kyllästysaste oli vähintään 73 \% vuosina 2006-2016. On kuitenkin huomattava, että Järvijoen mittauspaikka oli useita kilometrejä alavirtaan koepaikalta. Aineistoa ei ollut saatavilla tätä myöhemmiltä ajankohdilta. 
TAULUKKO 2 Vedenlaatu (keskiarvo \pm SE, alla min-max) Järvijoen suulla (syvyyksien $0,1-0,5 \mathrm{~m}$ keskiarvoja, $n=12$, alkaliniteetti ja happi, $n=27$, sameus, $\mathrm{pH}$, sähkönjohtavuus) ja Järvijoen yläpuolisella Savojärvellä (syvyyksien 0,5$1,0 \mathrm{~m}$ keskiarvoja, $n=19$, paitsi sulfaatti $n=1$ ) 2000-luvulla. Veden pH:lle on ilmoitettu pelkkä keskiarvo ja vaihteluväli. Aineisto on peräisin Suomen ympäristökeskuksen Hertta-tietokannasta (Suomen ympäristökeskus 2018b).

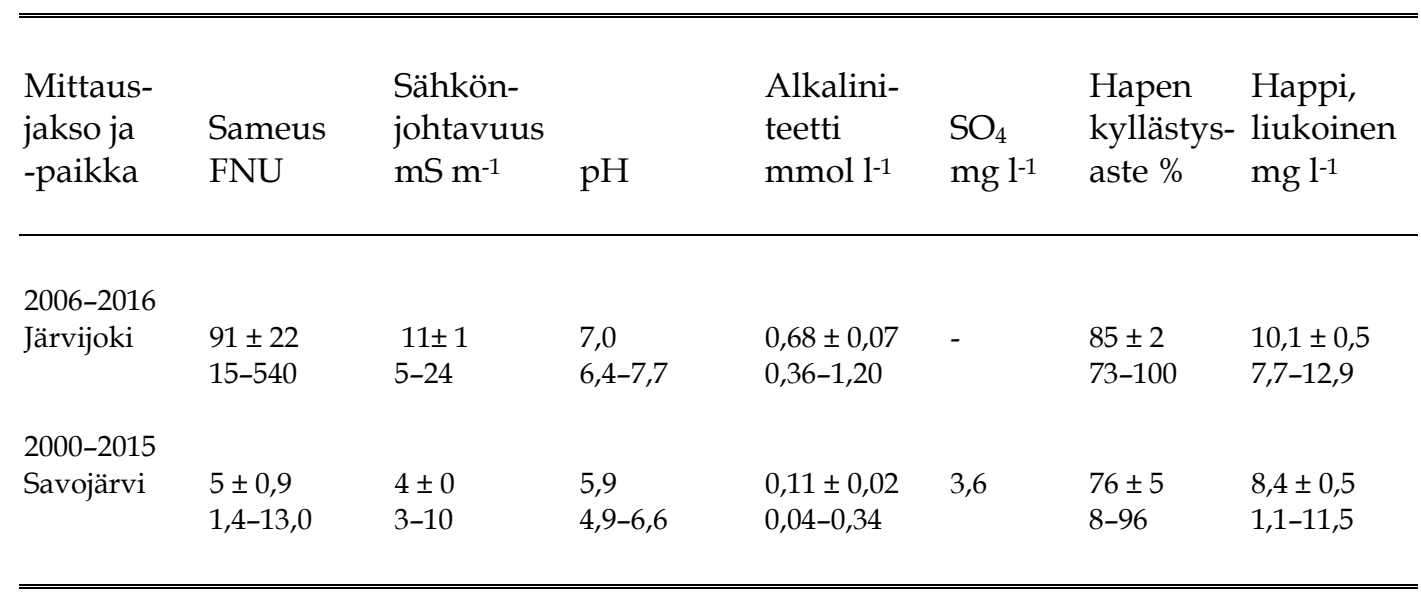

Savi- ja Järvijoen vertailualueilla veden syvyys oli suurimmillaan huhtikuussa (Taulukko 3). Savijoen kipsialueella sen sijaan vesisyvyys oli pääsääntöisesti suurimmillaan tammikuussa. Vastaavasti toukokuun lopussa veden syvyys oli matalimmillaan Savijoen koepaikoilla. Myös Järvijoen veden pinta oli tuolloin matalalla, mutta pienimmät arvot havaittiin maaliskuussa jään alta tehdyissä mittauksissa. Jokaisella tarkistus- tai näytteenottokerralla kaikki korit olivat veden alla, tosin maaliskuussa jää ulottui paikka paikoin pohjaan saakka Savijoen vertailualueella. 
TAULUKKO 3 Vesisyvyys $20 \mathrm{~cm}$ korin edessä ja keskimääräinen syvyys korin päällä Savijoen ja Järvijoen koepaikoilla. Alin, keski ja ylin viittaavat korin paikkaan joessa toisiinsa nähden.

Paikka Syvyys korin edessä $(\mathrm{cm})$

Syvyys korin päällä $(\mathrm{cm})$

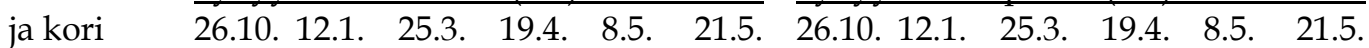

Savijoki, vertailu

$\begin{array}{llllllllllllll}\text { Alin } & 22 & 22 & - & 40 & 24 & 16 & 24 & 23 & - & 34 & 24 & 8\end{array}$

$\begin{array}{lllllllllllll}\text { Keski } & 35 & 44 & - & 51 & 43 & 22 & 35 & 33 & - & 48 & 35 & 22\end{array}$

$\begin{array}{lllllllllllll}\text { Ylin } & 29 & 33 & - & 39 & 22 & 11 & 23 & 22 & - & 35 & 25 & 14\end{array}$

Savijoki, kipsi

Alin 29

Keski $\quad 31$

$50-53$

$\begin{array}{llllll}\text { Keski } & 31 & 50 & - & 45 & 32\end{array}$

$\begin{array}{llllll}\text { Ylin } & 17 & 46 & - & 40 & 23\end{array}$

$\begin{array}{ccccccc}16 & 25 & 49 & - & 43 & 29 & 12 \\ 19 & 30 & 54 & - & 46 & 29 & 16 \\ 14 & 19 & 44 & - & 39 & 22 & 8\end{array}$

Järvijoki

$\begin{array}{lllllllllllll}\text { Alin } & 26 & 40 & 15 & 43 & 37 & 15 & 29 & 32 & 8 & 38 & 28 & 13\end{array}$

$\begin{array}{lllllllllllll}\text { Keski } & 25 & 34 & 6 & 34 & 28 & 12 & 27 & 32 & 9 & 36 & 28 & 12\end{array}$

$\begin{array}{lllllllllllll}\text { Ylin } & 29 & 34 & 2 & 37 & 32 & 6 & 28 & 32 & 11 & 37 & 31 & 16\end{array}$

Useimmilla paikoilla suurin virtausnopeus $20 \mathrm{~cm}$ korien edessä havaittiin tammikuussa (Taulukko 4). Virtausnopeus oli vastaavasti hitaimmillaan pääsääntöisesti toukokuun loppupuolella. 
TAULUKKO 4 Virran nopeus $2 \mathrm{~cm}$ pohjasta ja syvyydeltä $0,6 \times$ kokonaissyvyys $20 \mathrm{~cm}$ korin edessä Savijoen ja Järvijoen koepaikoilla. Alin, keski ja ylin viittaavat korin paikkaan joessa toisiinsa nähden.

Paikka Nopeus pohjalla $\left(\mathrm{cm} \mathrm{s}^{-1}\right)$

Nopeus $0,6 \times$ kokonaissyvyys $\left(\mathrm{cm} \mathrm{s}^{-1}\right)$

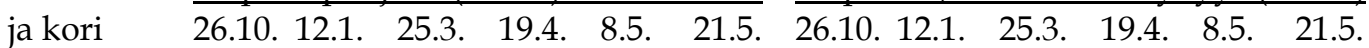

Savijoki, vertailu

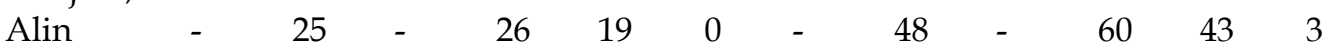

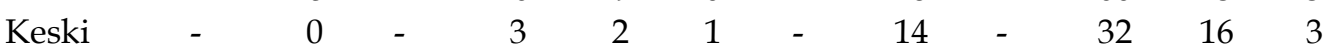

$\begin{array}{lllllllllllll} & \text { Ylin } \quad- & 13 & - & 13 & 12 & 0 & - & 54 & - & 47 & 21 & 5\end{array}$

Savijoki, kipsi

$\begin{array}{llllllllllllll}\text { Alin } & - & 27 & - & 5 & 24 & 5 & - & 80 & - & 13 & 44 & 1\end{array}$

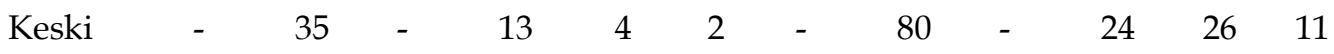

$\begin{array}{lllllllllllll}\text { Ylin } & - & 7 & - & 9 & 45 & 28 & - & 80 & - & 85 & 60 & 39\end{array}$

Järvijoki

$\begin{array}{lllllllllllll}\text { Alin } & - & 15 & 17 & 7 & 6 & 2 & - & 78 & 16 & 38 & 29 & 7\end{array}$

$\begin{array}{lllllllllllll}\text { Keski } & - & 29 & 12 & 16 & 12 & 19 & - & 61 & 2 & 42 & 44 & 21\end{array}$

$\begin{array}{lllllllllllll}\text { Ylin } & - & 28 & 15 & 12 & 2 & 46 & - & 88 & - & 25 & 51 & 42\end{array}$

Haudontakokeen alussa veden lämpötila sekä Savi- että Järvijoella oli noin $2{ }^{\circ} \mathrm{C}$ (Kuva 5). Paria joulukuun kylmempää vuorokautta lukuun ottamatta veden lämpötila Savijoen koepaikoilla laski alle $1{ }^{\circ} \mathrm{C}$ :een tammikuun alkupuolella, kunnes huhtikuun alkupuolella veden lämpötila lähti jälleen nousuun. Savijoen vertailualueella veden lämpötila oli pakkasen puolella 5.-8.3.2018, mutta kipsialueella ei havaittu negatiivisia lämpötilalukemia. Vastaavasti Järvijoella veden lämpötila laski alle $1^{\circ} \mathrm{C}$ jo joulukuun alkupuolella ja pysyi alle $1^{\circ} \mathrm{C}$ aina huhtikuun alkuun saakka (Kuva 5). Järvijoella veden lämpötila pysyi yli $0^{\circ} \mathrm{C}$ koko haudontajakson ajan. 


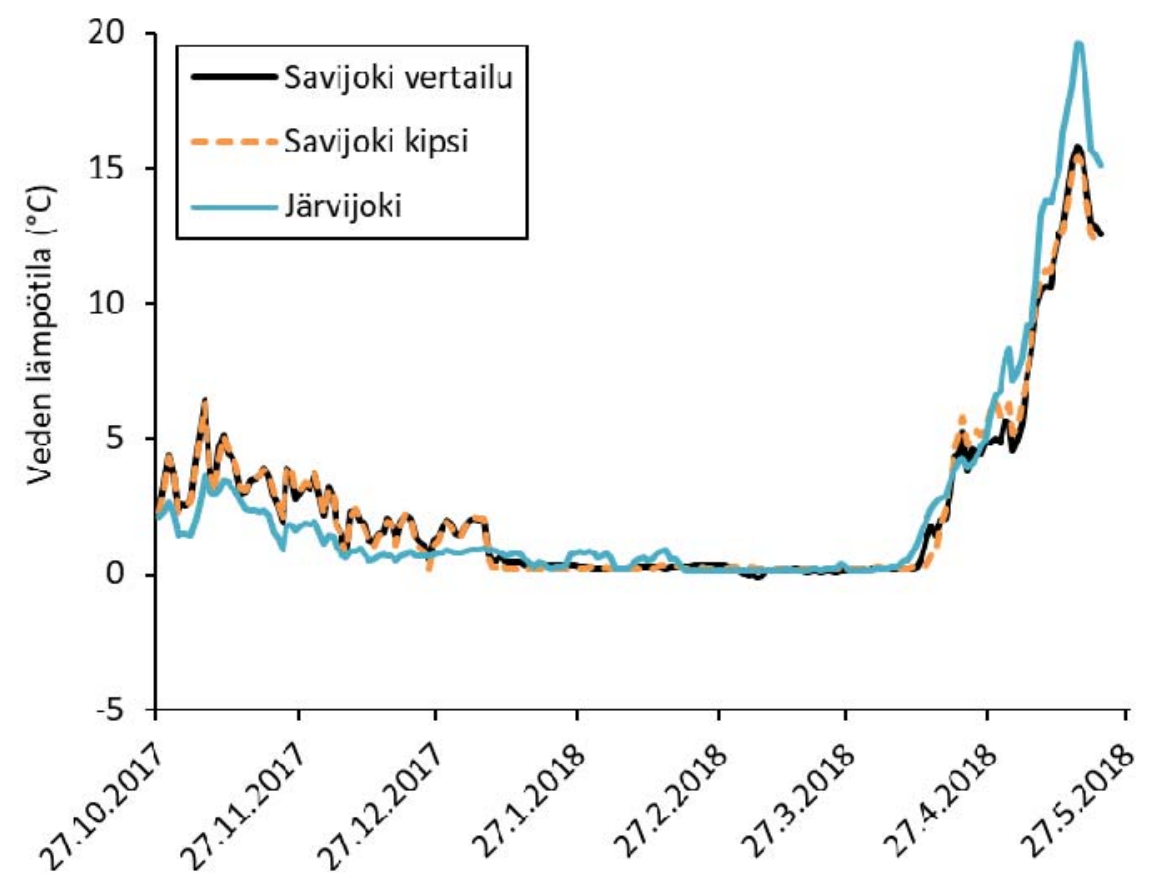

KUVA 5 Jokiveden keskimääräinen vuorokausilämpötila eri koepaikoilla tutkimusjaksolla 27.10.2017-21.5.2018. Jokiveden lämpötila on ilmoitettu kuvaajassa ensimmäisestä kokonaisesta vuorokaudesta alkaen, milloin lämpötilatallentimet olivat joissa.

Haudontakoejakson ensimmäisten kuukausien aikana Savi- ja Järvijoen välille muodostui huomattava ero päiväasteissa. Esimerkiksi huhtikuun näytteenottoon mennessä Savijoen koepaikoilla päiväastekertymä oli $238-241^{\circ} \mathrm{C}$, kun taas Järvijoella kertymä oli $177^{\circ} \mathrm{C}$. Jokien välinen ero pieneni kevään edetessä, ja päiväastekertymä koko koejaksolla oli 520-528 ${ }^{\circ} \mathrm{C}$ (Kuva 6). 


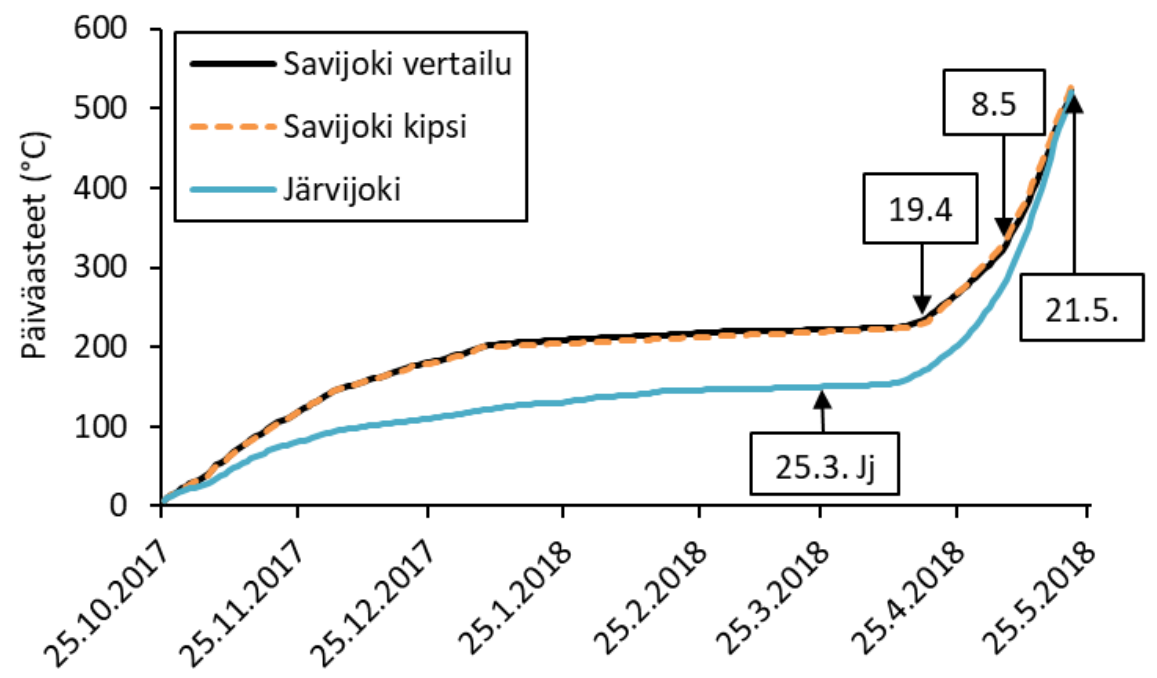

KUVA 6 Päiväastekertymät eri koepaikoilla alkaen mädin hedelmöityksestä. Näytteenottopäivät on osoitettu nuolilla. Maaliskuussa näytteet otettiin vain Järvijoen (Jj) koepaikalta, muilla kerroilla kaikilta koepaikoilta ja koe päättyi 21.5.2018.

Sylintereihin kertyi hiekkaa kaikilla koepaikoilla (Kuva 2c \& d). Silmämääräisesti tarkasteltuna hiekan osuuden keskiarvo ja vaihteluväli koko sylinterin sisällöstä oli Savijoen vertailupaikalla 33 ja 13-50 \% ja kipsipaikalla 35 ja 13-40 \%. Järvijoen sylintereissä hiekkaa oli vastaavasti 34 ja 25-50 \%.

Viimeisessä näytteenotossa millimetripaperilla tehtyyn tarkkaan raekokoanalyysiin kerättyjen sylintereiden sisällöstä 0-8 mm:n jaetta oli Savijoen vertailu- ja kipsipaikalla sekä Järvijoella 23, 35 ja $28 \%$. Seulontatuloksien perusteella 0-8 mm:n jakeesta vastaavasti 78, 88 ja $99 \%$ oli < 2 mm:n jaetta. Maastossa tehdyn silmämääräisen arvion mukaan vastaavat hiekan osuudet näissä sylintereissä olivat 33, 40 ja $33 \%$. Vallitseva raekoko suurimman halkaisijan perusteella oli 16-32 mm, mikä käsitti 44-47 \% sylinterin sisällöstä.

Millimetripaperilla tehdyn raekokoanalyysin perusteella koreihin oli kertynyt 0-8 mm:n jaetta eniten Savijoen kipsialueella ja Järvijoella, 13 \% molemmissa. Vastaava osuus Savijoen vertailualueella oli 8 \%. Seulontatuloksien mukaan kaikilla paikoilla 0-8 mm:n jakeesta suurin osa, 74-91 \%, oli alle $2 \mathrm{~mm}$ kokoista. Vallitseva raekoko suurimman halkaisijan perusteella oli 32-64 $\mathrm{mm}$, jota oli 32-50 \% korin sisällöstä.

\subsection{Säilyvyys, kuoriutuminen ja kasvu}

Varhaisten elinvaiheiden säilyvyys ja kuoriutuneiden osuus olivat yleisesti ottaen matalia, ja niissä oli huomattavaa sylintereiden välistä vaihtelua kaikilla koepaikoilla (Taulukko 5). Vaikka säilyvyys oli Järvijoella vielä maaliskuussa 
keskimäärin $78 \%$, niin huhtikuun näytteenottoon mennessä se oli laskenut voimakkaasti, keskimäärin 26 \%:iin. Savijoen koepaikoilla säilyvyys oli tätäkin matalampi. Huhtikuussa keskimääräinen säilyvyys Savijoen kipsinlevitysalueella ja vertailualueella oli 13 ja $7 \%$, ja molemmilla paikoilla eläviä alkioita oli vain yhdessä sylinterissä. Toukokuun alkuun mennessä keskimääräinen säilyvyys Savijoen vertailualueella oli enää 3 \% ja toukokuun lopulla $0 \%$. Kipsinlevitysalueen sylintereistä ei havaittu yhtään elävää yksilöä toukokuussa. Järvijoellakin säilyvyys oli laskenut entisestään ja oli toukokuun alussa keskimäärin 1 ja lopussa $9 \%$. Kaikki elävät alkiot olivat kuoriutuneet toukokuun näytteenottoihin mennessä, ja Savijoen koepaikkojen sylintereistä löydettiin myös kuolleita poikasia (Taulukko 5). Myös viimeisellä nostokerralla kerättyjen Savijoen vertailu- ja kipsipaikan ylimääräisissä sylintereissä säilyvyys oli kaikissa $0 \%$, eikä yksikään alkio ollut kuoriutunut näissä (nämä tulokset eivät ole mukana taulukossa 5 esitetyissä tuloksissa).

Alkioiden ja poikasten kasvu oli pääsääntöisesti positiivisesti yhteydessä päiväasteiden kertymiseen. Lisäksi alkioiden ja poikasten keskimääräinen pituus oli lähes sama kaikilla paikoilla kaikkina ajankohtina (Taulukko 5). 
TAULUKKO 5 Taimenen alkioiden ja poikasten säilyvyys, kuoriutuneet (elävät ja kuolleet kuoriutuneet suhteessa alun kokonaismunamäärään) ja alkioiden ja poikasten keskimääräinen pituus Savi- ja Järvijoen koepaikoilla eri näytteenottoajankohtina. Alin, keski ja ylin viittaavat korin paikkaan joessa toisiinsa nähden, ja näistä laskettu kunkin paikan näytteenottokohtainen keskiarvo ja eksakti $95 \%$ luotettavuusväli.

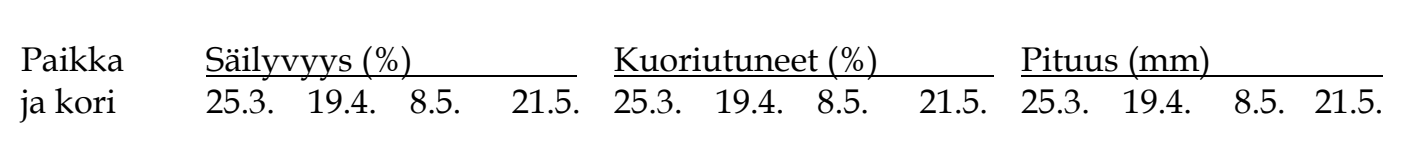

\begin{tabular}{|c|c|c|c|c|c|c|c|c|c|c|c|c|}
\hline \multicolumn{13}{|l|}{$\begin{array}{l}\text { Savijoki, } \\
\text { vertailu }\end{array}$} \\
\hline Alin & - & 22 & 10 & 0 & - & 0 & 14 & 0 & - & 14,4 & 19,0 & - \\
\hline Keski & - & 0 & 0 & 0 & - & 0 & 0 & 0 & - & - & - & - \\
\hline Ylin & - & 0 & 0 & 0 & - & 0 & 0 & 0 & - & - & - & - \\
\hline Keskiarvo & b - & 7 & 3 & 0 & - & 0 & 5 & 0 & - & 14,4 & 19,0 & - \\
\hline $95 \%$ & - & 4-13 & $1-8$ & $0-2$ & - & $0-2$ & $2-9$ & $0-2$ & - & - & - & - \\
\hline \multicolumn{13}{|l|}{$\begin{array}{l}\text { Savijoki, } \\
\text { kipsi }\end{array}$} \\
\hline Alin & - & 0 & 0 & 0 & - & 0 & 0 & 0 & - & - & - & - \\
\hline Keski & - & 0 & 0 & 0 & - & 0 & 4 & 2 & - & - & - & - \\
\hline Ylin & - & 38 & 0 & 0 & - & 0 & 2 & 0 & - & 14,8 & - & - \\
\hline Keskiarvo & - & 13 & 0 & 0 & - & 0 & 2 & 1 & - & 14,8 & - & - \\
\hline $95 \%$ & - & 8-19 & $0-2$ & $0-2$ & - & $0-2$ & $0-6$ & $0-4$ & - & - & - & - \\
\hline \multicolumn{13}{|l|}{ Järvijoki } \\
\hline Alin & 88 & 76 & 2 & 0 & 0 & 0 & 2 & 0 & 12,8 & 14,8 & 18,6 & - \\
\hline Keski & 84 & 2 & 0 & 0 & 0 & 0 & 0 & 0 & 12,1 & * & - & - \\
\hline Ylin & 62 & 0 & 0 & 26 & 0 & 0 & 0 & 26 & 12,4 & - & - & 25,9 \\
\hline Keskiarvo & b 78 & 26 & 1 & 9 & 0 & 0 & 1 & 9 & 12,5 & 14,8 & 18,6 & 25,9 \\
\hline $95 \%$ & $71-84$ & 19-34 & $0-4$ & 5-14 & - & - & $0-4$ & 5-14 & - & - & - & - \\
\hline
\end{tabular}

* Alkio katkesi avattaessa 


\section{TULOSTEN TARKASTELU}

Työn tavoitteena oli selvittää kipsinlevityksen vaikutusta taimenen varhaisten elinvaiheiden säilyvyyteen ja kasvuun Savijoella. Päätelmiä kipsinlevityksen vaikutuksista taimenen varhaisiin elinvaiheisiin ei kuitenkaan pystytty tekemään, sillä sylintereihin kertynyt hiekka häiritsi koetta. Alkioiden säilyvyys oli pieni kaikilla koepaikoilla, vaikka haudontakorien mikroympäristö vastasi pääsääntöisesti hyvin taimenen oikeiden kutupesien mikroympäristöä vesisyvyyden ja virrannopeuden osalta (ks. Witzel ja MacCrimmon 1983, Syrjänen ym. 2013). Kun haudontakokeita on tehty alueilla, joilla ihmistoiminnan vaikutukset ovat olleet vähäisiä, taimenen alkioiden säilyvyys on helmi-huhtikuussa ollut vähintään 83 \% (Syrjänen ym. 2008, Oraluoma ym. 2015). Sen sijaan ihmistoiminnan vaikutuksen alaisilla paikoilla säilyvyys on vaihdellut enemmän ja ollut jopa huomattavan heikkoa (Laine ym. 2001, Korsu ym. 2003, Sivonen ja Oraluoma 2014, Sivil 2015, Syrjänen 2016). Esimerkiksi maatalouskuormitteisissa virtavesissä taimenen mädin keskimääräinen säilyvyys ja vaihteluväli ovat lokakuusta helmikuulle olleet $84 \%$ ja 56-98 \% ja lokakuusta huhtikuulle $47 \%$ ja 22-70 \% (ks. Sivil 2015). Metsäojitettujen valuma-alueiden joissa säilyvyys on ollut samaa suuruusluokkaa kuin edellä (Korsu ym. 2003) tai alempi, jopa $0 \%$ (Sivonen ja Oraluoma 2014, ks. Syrjänen 2016 Taulukko 5). Savijoella taimenen alkioiden keskimääräinen säilyvyys oli siis suurelta osin matalampaa kuin aiemmin on havaittu vastaavan tyyppisissä virtavesissä. Tulokset eivät kuitenkaan olleet täysin poikkeuksellisia aiempiin tutkimuksiin nähden.

Haudontasylintereihin ja -koreihin kertynyt hiekka heikensi todennäköisesti alkioiden ja poikasten säilyvyyttä. Hyvä veden vaihtuvuus on oleellista alkioiden hapensaannin ja aineenvaihduntatuotteiden poishuuhtoutumisen kannalta (Crisp 1993), ja hienojakoisen aineksen on osoitettu heikentävän lohikalojen alkioiden selviytymistä ja poikasten sorastanousua ( $\mathrm{O}^{\prime} \mathrm{Connor}$ ja Andrew 1998, Sternecker ja Geist 2010). Esimerkiksi O'Connor ja Andrew (1998) havaitsivat, että lohen (Salmo salar) mädin säilyvyys voi heikentyä, jos hienojakoisen aineen (raekoko < $1 \mathrm{~mm}$ ) osuus nousee yli $10 \%$ :iin soran kokonaismassasta. Lisäksi hiekan vaikutus alkioihin ja poikasiin on voinut korostua kevään edetessä, sillä alkioiden hapenkulutus kasvaa veden lämpötilan noustessa ja riippuu myös kehitysvaiheesta ja on suurimmillaan kuoriutumisen aikoihin (Crisp 
1993, Greig ym. 2007). Toisaalta, aivan kuten joissakin aiemmissa haudontakokeissa (mm. O'Connor ja Andrew 1998, Syrjänen ym. 2008, Arola ym. 2018), hienojakoisen aineksen vaikutus ei tässäkään kokeessa ollut täysin yksiselitteinen. Esimerkiksi viimeisessä näytteenotossa Järvijoella havaitut elävät poikaset olivat sylinterissä, jonka sisällöstä 50 \% oli hiekkaa, kun taas kahdessa muussa sylinterissä, joissa säilyvyys oli 0 \%, hiekkaa oli 33 \%. O'Connor ja Andrew (1998) ovat osoittaneet, että vaikka laboratorio-oloissa hienojakoisen aineksen säilyvyyttä heikentävä vaikutus on selkeä, niin luonnossa erot säilyvyydessä eivät riippuneet kertyneen hienojakoisen aineksen määrästä. He arvelivat luonnossa havaitun riippumattomuuden johtuvan mahdollisista eroista mikroympäristöissä aivan haudontayksiköiden välittömässä läheisyydessä (O'Connor ja Andrew 1998). Kaiken kaikkiaan hiekan kertyminen sylintereihin häiritsi koetta, joten kipsin vaikutuksia taimenen mädin säilyvyyteen ei pystytty arvioimaan kunnolla.

Lisäksi haudontasylinterien mahdollinen jäätyminen on saattanut heikentää alkioiden säilyvyyttä Savijoen vertailualueella. Maaliskuun alussa kyseisellä koepaikalla havaittiin negatiivisia veden lämpötila-arvoja neljän vuorokauden ajan ja maaliskuun lopulla jääkannen havaittiin ulottuvan paikka paikoin pohjaan saakka. Toisaalta negatiiviset lämpötilahavainnot olivat enintään $-0,2{ }^{\circ} \mathrm{C}$, eli ne mahtuivat lämpötilatallentimien mittaustarkkuuden $\left(0,2^{\circ} \mathrm{C}\right)$ piiriin. Sen sijaan Savijoen kipsinlevitysalueella tammikuussa havaittu pohjajää ei näkynyt kyseiseltä paikalta mitatuissa veden lämpötila-arvoissa ainakaan negatiivisina lämpöasteina. Toukokuussa puolestaan veden lämpötilan nousu yli $11^{\circ} \mathrm{C}: n$ on voinut heikentää säilyvyyttä, sillä $11^{\circ} \mathrm{C}: n$ ja sitä korkeamman veden lämpötilan on osoitettu häiritsevän taimenen alkionkehitystä (Lahnsteiner 2012).

Yksilöiden pituudessa ei havaittu huomattavia eroja eri koepaikkojen välillä. Savi- ja Järvijoen koepaikkojen alkioiden ja poikasten pituuksia ei kuitenkaan pystytty kunnolla vertailemaan toisiinsa johtuen suppeasta pituusmittausaineistosta. Kokonaisuudessaan alkioiden ja poikasten keväänaikainen kasvu noudatti päiväastekertymää. Verrattuna esimerkiksi aiempaan Kymijoen vesistöalueen Tourujoella, Autiojoella ja Syväojalla tehtyyn mädinhaudontakokeeseen (Syrjänen 2016) alkioille ja poikasille oli Savi- ja Järvijoella kertynyt huhtikuun ja toukokuun ensimmäiseen näytteenottoon mennessä vähemmän päiväasteita kuin näillä kolmella joella vastaaviin ajankohtiin mennessä. Niinpä alkiot ja poikaset olivat myös pääsääntöisesti pienempiä tässä kokeessa.

Haudontakoejaksolla terminen talvi alkoi Lounais-Suomessa 7.1.2018 ja terminen kevät 4.4.2018 (Ilmatieteen laitos 2018a ja b). Kolmenkymmenen vuoden keskiarvoihin nähden terminen kevät alkoi hieman myöhemmin, mutta poikkeama oli normaalin vaihtelun rajoissa (Ilmatieteen laitos 2018b). Turussa mitattujen säähavaintojen perusteella ilman lämpötila haudontakoejaksolla oli marras-tammikuussa $2,2-3,4^{\circ} \mathrm{C}$ korkeampi kuin 30 vuoden keskiarvo (Ilmatieteen laitos 2018c). Vastaavasti helmi- ja maaliskuu olivat $2,3-2,5^{\circ} \mathrm{C}$ kylmempiä, kun taasen toukokuun keskilämpötila oli $5,2^{\circ} \mathrm{C}$ lämpimämpi (Ilmatieteen laitos 2018c). Loka- ja varsinkin joulukuu olivat sateisia, ja joulukuun sademäärä 131 mm oli noin kaksinkertainen 30 vuoden keskiarvoon nähden (Ilmatieteen laitos 
2018c). Sitä vastoin helmi-, maalis- ja toukokuun sademäärät olivat pienempiä pitkäaikaiseen keskiarvoon nähden (Ilmatieteen laitos 2018c).

Vuosien väliset erot Savijoen valunnassa voivat olla suuria (Kuva 4a). Jaksolla 1.1.2016-31.5.2018 syksyn ja talven aikaisessa valunnassa oli suurta vuosien välistä vaihtelua. Sen sijaan kevään valunnassa ei ollut yhtä suuria eroja eri vuosien välillä. Koska Savijoella on vuosien välistä vaihtelua haudontaoloissa, haudontakoe olisikin hyvä toistaa. Toistamista puoltaa myös se, että haudontakoe tehtiin vasta toisena kipsin levityksen jälkeisenä talvena, jolloin sulfaattipitoisuudet olivat jo jonkin verran pienempiä kuin ensimmäisenä talvena (Kuva $4 b)$.

\section{KIITOKSET}

Tämä tutkimus toteutettiin Suomen ympäristökeskuksen ja Jyväskylän yliopiston bio- ja ympäristötieteiden laitoksen yhteistyönä. Tutkimus oli osa ympäristöministeriön rahoittamaa SAVE-hanketta (Saaristomeren vedenlaadun parantaminen peltojen kipsikäsittelyllä). Kiitos Maija Hannulalle, Janne Koskiselle, Jonna Kuhalle ja Jouni Saloselle maastotyöavusta ja Maijalle myös avustuksesta laboratoriotyössä ja raportin kommentoinnista. Kiitos myös Petri Ekholmille suunnittelusta, vedenlaatutietojen toimittamisesta sekä raportin kommentoinnista ja Jukka Syrjäselle suunnittelusta, taustatuesta ja raportin kommentoinnista. Mädinhaudontasylinterit oli lainattu Konneveden kalatutkimus ry:lta, jolle ne olivat tulleet lahjoituksena Anssi Elorannalta. Kiitos myös kaikille paikallisille tahoille yhteistyöstä Savi- ja Järvijoella. 


\section{LÄHDELUETTELO}

Arola H.E., Karjalainen A.K., Syrjänen J.T., Hannula M., Väisänen A. \& Karjalainen J. 2018. Assessment of fish embryo survival and growth by in situ incubation in acidic boreal streams undergoing biomining effluents. Arch. Environ. Contam. Toxicol. (painossa).

Crisp D. T. 1993. The environmental requirements of salmon and trout in fresh water. Freshwater Forum 3: 176-202.

Elphick J.R., Davies M., Gilron G., Canaria E.C., Lo B. \& Bailey H.C. 2011. An aquatic toxicological evaluation of sulfate: the case for considering hardness as a modifying factor in setting water quality guidelines. Environ. Toxicol. Chem. 30: 247-253.

Greig S.M., Sear D.A. \& Carling P.A. 2007. A review of factors influencing the availability of dissolved oxygen to incubating salmonid embryos. Hydrol. Process. 21: 323-334.

Ilmatieteen laitos. 2018a. Ilmasto, Talvitilastot. www.ilmatieteenlaitos.fi/talvitilastot. (luettu 6.7.2018).

Ilmatieteen laitos. 2018b. Ilmasto, Kevättilastot. www.ilmatieteenlaitos.fi/ kevattilastot. (luettu 6.7.2018).

Ilmatieteen laitos. 2018c. Ilmasto, Tilastoja vuodesta 1961. www.ilmatieteenlaitos.fi/ilmasto/tilastoja-vuodesta-1961. (luettu 6.7.2018).

Korsu K., Kiljunen M., Karjalainen J., Syrjänen J. \& Eloranta A. 2003. Taimenen (Salmo trutta) ja harjuksen (Thymallus thymallus) mädin hautoutuminen Rautavaaran seudun happamissa joissa. Kala- ja riistahallinnon julkaisuja 64: 52-78.

Koski T., Aaltonen J., Laaksonlaita J., Huhta E., Tolonen J., Narkinniemi J. \& Tähtinen J. 2013. Taimen Turun seudun virtavesissä, Kalataloudellinen kunnostustarvekartoitus. Laaksonlaita J. \& Huhta E. (toim.). Turun ammattikorkeakoulun raportteja. 165: $104 \mathrm{~s}$.

Lahnsteiner F. 2012. Thermotolerance of brown trout, Salmo trutta, gametes and embryos to increased water temperatures. J. Appl. Ichthyol. 28: 745-751.

Laine A., Heikkinen K. \& Sutela T. 2001. Incubation success of brown trout (Salmo trutta) eggs in boreal humic rivers affected by peatland drainage. Arch. Hydrobiol. 150: 289-305.

Maanmittauslaitos 2018. Avoimien aineistojen tiedostopalvelu. https://www.maanmittauslaitos.fi/asioi-verkossa/avoimien-aineistojentiedostopalvelu. (Suomen yleiskartta, ladattu 11/2016, ja maastokartta, ladattu 2/2018).

O'Connor W.C.K. \& Andrew T.E. 1998. The effects of siltation on Atlantic salmon, Salmo salar L., embryos in the River Bush. Fisheries Manag. Ecol. 5: 393-401.

Oraluoma M., Kivinen J. \& Sivonen K. 2015. Mädinhaudontakoe Viitasaaren Kärnänkoskella \& Kyrönpurolla 2014-2015. Kala- ja vesistötutkimus Vesi-Visio. 
Sergeant E.S.G. 2018. Epitools epidemiological calculators. Ausvet Pty Ltd. http:/ / epitools.ausvet.com.au. (luettu 12/2018).

Sivil M. 2015. Kokonaisselvitys Kuortaneenjärven alapuolisen Lapuanjoen ekologisen tilan parantamismahdollisuuksista - hankeselvitysten tulokset ja suositukset vesienhoidolle. Etelä-Pohjanmaan elinkeino-, liikenne- ja ympäristökeskus. $238 \mathrm{~s}$.

Sivonen O. \& Oraluoma M. 2014. Mädinhaudontakoe Petäjäveden Pengerjoella ja Ohrajoella 2013-2014. Kala- ja vesistötutkimus Vesi-Visio.

Sternecker K. \& Geist J. 2010. The effects of stream substratum composition on the emergence of salmonid fry. Ecol. Freshw. Fish. 19: 537-544.

Suomen ympäristökeskus. 2018a. Avoin tieto, Paikkatietoaineistot, Latauspalvelu LAPIO. http://www.syke.fi/fi-FI/Avoin_tieto/Paikkatietoaineistot. (Ranta10 - joet, ladattu 7/2018, Ranta10 - uomaverkostot, ladattu 7/2018).

Suomen ympäristökeskus. 2018b. Avoin tieto, Avoimet ympäristöjärjestelmät. http:/ / www.syke.fi/avoindata. (luettu 5/2018 ja 6/2018).

Syrjänen J. 2016. Taimenen mädin säilyvyys haudontakokeessa Jyväskylän Tourujoen vesistössä talvella 2015-2016. Konneveden kalatutkimus ry:n työraportteja 2016(2): 1-14.

Syrjänen J., Kiljunen M., Karjalainen J., Eloranta A. \& Muotka T. 2008. Survival and growth of brown trout Salmo trutta L. embryos and the timing of hatching and emergence in two boreal lake outlet streams. J. Fish Biol. 72: 985-1000.

Syrjänen J.T., Sivonen K., Sivonen O. \& Valkeajärvi P. 2013. Taimenen kutupesälaskenta - menetelmät ja esimerkkituloksia. Riista- ja kalatalous - Tutkimuksia ja selvityksiä. 2013(9): 1-28.

Wang N., Dorman R.A., Ingersoll C.G., Hardesty D.K., Brumbaugh W.G., Hammer E.J., Bauer C.R. \& Mount D.R. 2016. Acute and chronic toxicity of sodium sulfate to four freshwater organisms in water-only exposures. Environ. Toxicol. Chem. 35: 115-127.

Witzel L.D. \& MacCrimmon H.R. 1983. Redd-site selection by brook trout and brown trout in southwestern Ontario streams. Trans. Am. Fish. Soc. 112: 760-771. 